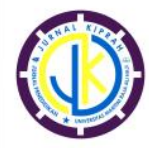

http://ojs.umrah.ac.id/index.php/kiprah

p-ISSN 2354-7278 | e-ISSN 2580-6947

\title{
The Development of Animal Physiology Handbook based on Scientific Approached for Students at Biology Program
}

\author{
Diah Putri Anggun* \\ Pendidikan Biologi, UIN Raden Fatah Palembang, Palembang, Indonesia \\ Pengiriman: 05/10/2020; Diterima: 22/06/2021; Publikasi: 29/06/2021 \\ DOI: $10.31629 /$ kiprah.v9i1.2570
}

\begin{abstract}
Abstrak
Kegiatan praktikum pada matakuliah fisiologi hewan membutuhkan penuntun praktikum yang dapat membimbing mahasiswa menguasai materi melalui aktivitas praktikum berbasis pendekatan saintifik. Penuntun praktikum memiliki pendekatan spesifik dalam membimbing mahasiswa untuk meningkatkan kompetensinya. Penelitian ini bertujuan untuk menggambarkan proses pengembangan penuntun praktikum berbasis pendekatan saintfik untuk menghasilkan penuntun praktikum yang valid dan praktis. Penelitian ini menggunakan model pengembangan Plomp yang tergabung dalam tiga fase utama, yaitu penelitian pendahuluan, pengembangan prototipe dan tahap penilaian. Instrumen penelitian ini adalah angket validitas dan praktikalitas. Data dianalisis secara deskriptif dan statistic. Data hasil penelitian menunjukkan bahwa penuntun ini sudah valid untuk digunakan. Hal ini menunjukkan bahwa, penuntun praktikum memiliki kualitas yang baik berdasarkan penilaian para validator di bidang koten, konstruk, teknis dan Bahasa. Berdasarkan hasil uji praktiklaitas oleh dosen dan mahasiswa, penuntun juga menujukkan hasil yang baik, yakni praktis untuk digunakan dalam kegiatan praktikum.
\end{abstract}

Kata Kunci: fisiologi hewan; kompetensi mahasiswa; penuntun praktikum

\begin{abstract}
Practical activity of Animal Physiology subject requires a handbook that can guided students master the material through practical activity based on a scientific approached. Handbook has a specific approached in order to guide students improved their competencies. The research aimed to describe the developmental process of handbook based on scientific approach and to produce a valid and practice handbook. The research used Plomp models which consisted three phase involving of preliminary research, development or prototype, and assessment phase. The instruments of data collection were obtained from handbook validity sheets, practicality questionnaires for lecturers and students. The data was analyzed descriptively and statistically. The results showed us that animal physiology handbook based on scientific approach is valid. It meant that the practical handbook has a good quality based on the assessment from the expert of content, constructive, technique, and language. The lecturers and students categorized this handbook as very practical since it is easy to used.
\end{abstract}

Keywords: animal physiology; handbook; students' competences

\section{INTRODUCTION}

Practical activity is a teaching and learning activity that aims to strengthen students' knowledge of subject matter through application, analysis, synthesis, and evaluation of the theory being studied, both in the laboratory and in the field. Practical activities not only prove the theory that students learn, but also serve to train and improve the scientific process. Practicum is mandatory for every student (Nurmawati and Sulistiawan, 2011). Practical activities are held in the form of observations and experiments in or outside the laboratory.

Animal physiology handbook is one of the teaching materials used to strengthen the 
concepts and theories obtained by students from the animal physiology lecture process. The aim of animal physiology lectures is for students to be able to master the theoretical concepts of animal physiology of vertebrate animals (organization at the level of tissues, organs, and organ systems) in general, and to master animal physiology in depth. Based on the results of the practicality questionnaire on the old handbook, it was found that the handbook used was not able to help explain abstract subject concepts and the practitioner could not fully report the results of the practicum in accordance with scientific steps, such as making observations, formulating problems, collecting data, and draw conclusions, this is revealed from $23.3 \%$ of the respondents' answers. As many as $20 \%$ of respondents 'answers also stated that the handbook did not yet have the use of language that was easy to understand, $16.6 \%$ of the respondents answered that the handbook did not have an easy to understand work order, and $13.3 \%$ of the respondents' answers stated that the practitioner did not have initial knowledge or readiness. before doing practicum.

Handbook based on a scientific approach is a guide that can hone practical skills and is in accordance with the level of students' thinking abilities (Daryatno, 2014). This is because handbooks based on a scientific approach will refer to evidence from objects that can be observed, empirical, and measurable with specific principles of reasoning. This is related to the characteristics of the scientific approach which generally includes a series of activities to observe, ask, conduct experiments, reason, and communicate (Kemendikbud, 2013).

The results of Abduh's research (2018), a scientific approach is included so that students know, understand, and build knowledge through scientific means. This, when studied further, will find a slice between the tasks of students and the tasks of the teacher in the scientific approach. On the one hand, students must perform process skills which in K13 are translated into 5M, namely, Observing, Asking, Trying, Associating, and Communicating. Hartono's research results (2015) show that a scientific approach can improve student learning outcomes. Factors that can improve student learning outcomes are motivation, interests, talents, supporting facilities and infrastructure, teachers, physical health, gender, and previous educational background.

Animal physiology handbook based on a scientific approach was developed using the 2013 Plomp model. The stages carried out are preliminary research (problem identification and analysis stage), prototyping phase (development and prototyping stage), assessment phase (Plomp, 2013).

\section{RESEARCH METHOD}

This development research used the Plomp development model. The stages taken are preliminary research (problem identification and analysis stage), development or prototyping phase (development and prototyping stage), assessment phase (assessment stage).

\section{Preliminary Research Phase}

At this stage, a situation and problem analysis is carried out in the Animal Physiology course, curriculum analysis, student analysis, and handbook analysis.

\section{Development or Prototyping Phase}

The development of a practical guiding framework, competency assessment sheets for students' cognitive, affective, and psychomotor domains was carried out. Furthermore, the practical guiding framework that has been planned is realized so as to produce a guideline for Animal Physiology practicum based on a scientific approach (prototype I).

The results of the prototype I are then reviewed by the researcher (Self Evaluation), whether they are in accordance with the components contained in the handbook and are ready to be tested for validity by experts (Expert Review) so as to produce prototype II. At this stage, the validity test is carried out based on the content validity and the construct validity. Furthermore, a trial phase consisting of three stages is carried out, including the one to one test, the Small Group test and the field test. 


\section{Assesment Phase}

The assessment stage aims to produce a product in the form of a practical and effective handbook based on a scientific approach. The assessment stage includes practicality testing and effectiveness testing.

The types of data in this study consist of two, namely qualitative and quantitative data. Qualitative data were obtained from the results of discussions, observations of the practicum process, and interviews with lecturers in the Animal Physiology course and students of the Department of Biology at UIN Raden Fatah Palembang. This qualitative data was also obtained from curriculum analysis, handbooks from several universities, and analysis of student needs for handbooks. Quantitative data were obtained from the results of practical questionnaires filled out by students and lecturers in the Animal Physiology course at the small group stage and field tests, observation sheets filled out by observers during practical activities to see the achievement of affective and psychomotor competencies, and learning outcomes tests conducted by students. at the end of practical activities. Data collected by two steps:

1. Validation instrument for handbook

The validation instrument is in the form of a handbook validation sheet. Analysis of assessments given by experts (experts) on didactic, construct, technical and language aspects.

2. Practicality Instrument Handbook

This instrument is used to collect practicality data. This instrument consists of a questionnaire for the responses of lecturers, practicum supervisors and students.
This is the stage of the evaluative layer of Plomp development model

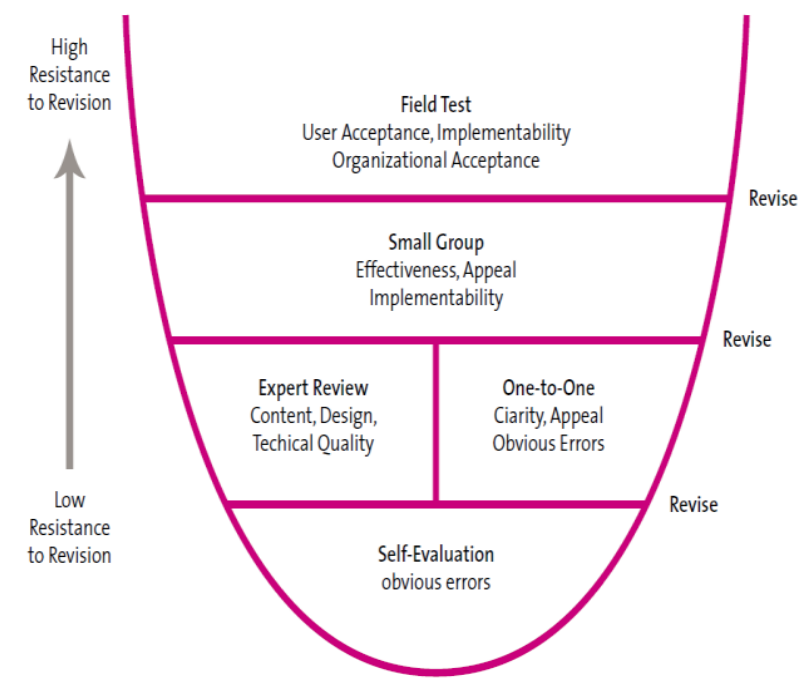

Figure 1. Stage of Evaluative Layer (Plomp, 2013)

The data collected from this study were the results of the validation, practicality, and effectiveness of the handbook. This data was analyzed by descriptive analysis. The feasibility data for this handbook is in the form of 1-4 Likert (Arikunto, 2012).

Student competency assessment data in the cognitive domain were obtained through tests at the end of the practicum in the form of multiple choice or objective questions.

\section{RESULT AND DISCUSSION}

This developed animal phisiology handbook contains five steps of the scientific approach. The observing activities will be carried out by reading the basic theory, observing pictures along with picture descriptions, and observing available tools and materials. This will provide students with initial knowledge of what will be practiced, so that students are better prepared to carry out practical activities. In line with the opinion of Hosnan (2014) that with the observation students will get a better understanding of the context in which the thing being researched exists or occurs. 1. Preliminary Research

At this stage, a situation and problem analysis is carried out in the Animal Physiology 
course, curriculum analysis, student analysis, and handbook analysis.

a. Analysis of Problems in Animal Physiology Practical Activities

Based on the interview, several facts were found including: the suitability of learning outcomes in lectures and the objectives of practical activities has not been described, even on all topics of practical activities there is no purpose of practical activities. This results in students not having a reference to achieve completeness criteria in practical activities.

Learning outcomes that have been developed in accordance with the demands of the Indonesian National Qualifications Framework (KKNI). KKNI provides measuring parameters in the form of qualification levels. For the undergraduate level it is at level 6.

b. Currucullar Analysis

At this stage, a review of the curriculum is carried out. The analysis is carried out on the guidance of learning outcomes and indicators outlined in the Animal Physiology practicum on the subject matter.

c. Guiding Analysis

The results of the handbook analysis include: on the material aspects / theoretical studies, preliminary studies and content, evaluation, approaches, and language.

d. Development or Prototyping Phase

At this stage, the researcher designed an Animal Physiology handbook based on a scientific approach. The presentation of the handbook is processed using Microsoft Office Word.
Table 1. The Analysis of Instrument Validation

\begin{tabular}{lcc}
\hline \multicolumn{1}{c}{ Indicators } & Score & Cathegory \\
\hline $\begin{array}{l}\text { The linkage of the } \\
\text { questionnaire } \\
\text { indicators is in } \\
\text { accordance with the }\end{array}$ & 3.00 & Valid \\
statement items in the \\
questionnaire. \\
$\begin{array}{l}\text { The statement used } \\
\text { includes aspects that } \\
\text { contain validity of } \\
\text { handbook based on } \\
\text { scientific approached }\end{array}$ & 3.00 & Valid \\
$\begin{array}{l}\text { The sentence used } \\
\text { based on correct }\end{array}$ & 3.00 & \\
$\begin{array}{l}\text { Indonesian rules } \\
\text { Score } \\
\text { Mean }\end{array}$ & & \\
\end{tabular}

Table 2. Recapitulation of Validator's Result

\begin{tabular}{clccc}
\hline No & Indicator & Score & Mean & $\begin{array}{c}\text { Catheg } \\
\text { ory }\end{array}$ \\
\hline 1 & Content & 27 & 3.40 & Valid \\
2 & Media & 28 & 3.30 & Valid \\
3 & Technic & 28 & 3.30 & Valid \\
4 & Language & 15 & 3.45 & Valid \\
$\begin{array}{c}\text { Jumlah } \\
\text { Keseluruhan } \\
\text { Rata-rata }\end{array}$ & \multicolumn{2}{c}{$\mathbf{9 8}$} & \\
\hline
\end{tabular}

Prototype III was developed after testing one on one (One to One). The one-to-one test (One to One) was carried out by asking the responses of eight students to get suggestions for improvement.

After making improvements / revisions to the handbook, the small group test was continued to get suggestions for improvements to the handbook that was developed. The Small Group Test was conducted on 16 students.

The results of the practical assessment assessed by the lecturer and the results of the practical assessment assessed by the lecturers and practicum supervisors using a scientific approach-based Animal Physiology lab guide are very practical.

The handbook is declared valid because it has fulfilled four aspects, namely didactic, construct, technical, and language aspects. The animal physiology practicum guide based on a scientific approach has fulfilled the didactic aspect because the theoretical basis in the 
practicum guide supports the achievement of indicators and learning objectives, supports concept understanding, and contains pictures which helps students in understanding the material. In accordance with the opinion of Rustaman (2007), that the learning media developed must be in accordance with the learning objectives. In addition, the handbook also includes a scientific approach, namely observing, asking, trying, reasoning, and communicating which helps to hone students' scientific skills in practical activities (BoeszeBattaglia, 2011). This can be seen in the statement of the test questionnaire the validity of the didactic aspects which are included in the very valid category.

Table 3. Practicality of Handbook

\begin{tabular}{clcc}
\hline No. & Indicator & Score & Cathegory \\
\hline 1 & $\begin{array}{l}\text { Ease of use } \\
\text { of the } \\
\text { handbook }\end{array}$ & 3.55 & Very practice \\
2 & $\begin{array}{l}\text { Time } \\
\text { required for } \\
\text { implementati } \\
\text { on }\end{array}$ & 3.33 & practice \\
3 & $\begin{array}{l}\text { Ease of } \\
\text { interpretatio } \\
\text { n }\end{array}$ & 4.00 & Very practice \\
4 & $\begin{array}{l}\text { Has } \\
\text { anquivalent } \\
\text { Mean }\end{array}$ & 3.80 & Very practice \\
\hline
\end{tabular}

Practical guide sheet for animal physiology handbook based on scientific approach is used to determine the response of course lecturers and practicum supervisors regarding the practicality of the products developed. This practicality sheet is in the form of a questionnaire filled out by subject lecturers and practicum supervisors after carrying out practical activities (Haryanto, 2011). According to Purwanto (2012) the practicality of a research product is important to note, and a product is said to have good practicality if it is possible to use the product. From the analysis of the practicality test questionnaire assessed by the students, it can be concluded that the practicality average value of the students is 3.25 in the practical category. This means that the Animal Physiology handbook used can facilitate students in practical activities, usefull of time allocations, are easily interpreted by students, and have the same equivalence as the practicum used in tertiary institutions (Roza, 2015).

Based on the results of development research that has been carried out, produce a scientific approach-based animal physiology handbook that valid, practical, and effective. Using this practical guide, you can make the process of active learning activities and can improve science skills of college student. The scientific approach-based animal physiology handbook can hone science skills and improve students' thinking skills.

This handbook can be used by lecturers and students in implementation of the practicum because it has been valid, practical, and effective and can allows simultaneous assessment of cognitive, affective, and psychomotor.

The process of developing this handbook has advantages because: using the stages of a scientific approach. In addition, it is easy to use by students because it is designed with a straightforward and effective grammar (Sani, 2014). This research can be used as teaching material to be used in the implementation of activities animal physiology practicum at university. This is because the handbook of animal physiology based on scientific approach can improve cognitive, affective, and psychomotor competencies of students.

Things that must be considered in developing a practical guide is the validity, practicality, and effectiveness of the developed guide This is because it will determine the quality of the handbooks that are prepared.

The creative ability of lecturers is also very much needed in selecting and utilizing existing learning resources and adapted to the appropriate approach will be used in the learning process. A scientific approach-based animal physiology practicum guide can facilitate students to learn independently, reduce the burden on lecturers in explaining learning material repeatedly, and can change the role of the lecturer from a teacher to a facilitator. The scientific approach has a close 
relationship with biological material because this approach emphasizes activeness in learning, and provides opportunities to build concepts in their knowledge independently, familiarize students with formulating, dealing with, and solving problems found (Johari et al, 2014).

\section{CONCLUSION}

The results of the validation by the validators show that the handout of animal physiology based on scientific approach reaches valid category based on criteria that can be used by lecturers, practical activity supervisors, and students at Laboratory. The results of the practicality test conducted by the lecturer, practical supervisor, and students show that the animal physiology handout based on scientific approached reaches a practical category so that it can be used by lecturers, practical supervisors, and students at Laboratory. Hopefully, for further research can proceed to the effectiveness stage to see if this handbook can improve students' cognitive, psychomotoric, and affective competence.

\section{ACKNOWLEDGMENT}

This study was funded by Anggaran DIPA UIN Raden Fatah Palembang year of 2020, through output-based research activities by LP2M UIN Raden Fatah Palembang.

\section{REFERENCES}

Arikunto, Suharsimi. (2012). Dasar-Dasar

Evaluasi Pendidikan Edisi 2. Jakarta:

Bumi Aksara.

Boesze-Battaglia, Kathleen dan Claire

Mitchelle. (2011). Different Scientific

Approach: One GoaL. Penn Dental

Journal. 7:1-7

Daryatno. (2014). Pendekatan Pembelajaran

Saintifik Kurikulum 2013. Yogyakarta:

Gava Media

Haryanto. (2011). Perencanaan Pengajaran.

Jakarta: PT. Rineka Cipta.

Hosnan, (2014). Pendekatan Saintifik dan

Kontekstual dalam Pembelajaran

Abad 21 Kunci Sukses Implementasi
Kurikulum 2013. Jakarta: Ghalia Indonesia.

Johari, Marjan., I.B. Putu Arnyana., I.G.A.

Nyoman Setiawan. (2014). "Pengaruh

Pembelajaran Pendekatan

Saintifik terhadap Hasil Belajar Biologi

dan Keterampilan Proses Sains

Siswa MA Mu'allimat NW Pancor Selong

Kabupaten Lombok Timur Nusa

Tenggara Barat". E-Journal Program

Pascasarjana Universitas

Pendidikan Ganesha. 4. "12".

Kemendikbud. (2013). "Pendekatan

Pendekatan Ilmiah dalam Pembelajaran".

Diklat Guru dalam Rangka Implementasi

Kurikulum 2013; Konsep Pendekatan

Saintifik. Bandung.

Plomp, Tjeerd. (2013). Educational Design Research; An Introduction.

Netherlands: Enschende.

Purwanto, Ngalim. (2004). Prinsip-prinsip dan Teknik Evaluasi Pengajaran.

Bandung: Remaja Rosdakarya.

Putri, Suci Aulia. (2016). "Pengembangan Penuntun Praktikum Anatomi Fisiologi Hewan Berbasis Pendekatan Inkuiri Bebas Dimodifikasi untuk Mahasiswa Jurusan Biologi". Tesis tidak diterbitkan. Padang: UNP.

Rustaman, N.Y. (2007). Program Pembelajaran

Praktikum berbasis Kemampuan

Generik (P3BKG) dan Profil

Pencapaiannya.

http://file.upi.edu/direktori/SPS/Prodi_Pe

nd dikan_IPA

19620115198701. pdf). (online). Diakses Juli 2015.

Roza, R.K. (2015). "Pengembangan Penuntun Praktikum Biologi Berbasis Pendekatan

Saintifik untuk MTs/SMP

Kelas VII Semester II”. Tesis. Padang:

Universitas Negeri Padang.

Sani, Ridwan Abdullah. 2014. Pembelajaran

Saintifik untuk Implementasi Kurikulum

2013. Jakarta: Bumi Aksara.

Sudijono, Anas. (2011). Pengantar Evaluasi Pendidikan. Jakarta: Raja Grafindo. 
D. P. Anggun / Jurnal Kiprah 9 (1) (2021) 67-73

Trianto. 2010. Model Pembelajaran Terpadu dalam Teori dan Praktek. Surabaya: Pustaka Ilmu.

Widhy. P. (2014). "Pembelajaran Kimia

Berbasis Laboratorium". Penelitian
Pembelajaran FMIPA

Berbasis

Laboratorium. Yogyakarta, 18 Januari 2010. 